\section{Notes}

1. For an interesting explanation of the active learning approach, see Frederick (1989).

2. It is hoped that during the discussion and performance phases that instructors are able to accomplish what P. J. Palmer describes as "hearing people into speech" by creating a situation in which they are "committed to serious [albeit, sometimes humorous] listening." See Palmer (1990).

3. See Fuentes (1990: 134-35).

\section{References}

Adelman, I. 1975. "Growth, Income Distribution and Equity Oriented Development Strategies." World Development : 67-76.

Frederick, P. J. 1989. "Involving Students More Actively in the Classroom." In The Department Chairperson's Role in Enhancing College Teaching, ed. A. F. Lucus. San Francisco: Jossey-Bass, 31-40.

Fuentes, C. 1990. The Death of Artemio Cruz. New York: The Noonday Press.

Palmer, P. J. 1990. "Good Teaching: A Matter of Living the Mystery." Change 22: 15 .

Weaver, J. and K. Jameson. 1981. Economic Development: Competing Paradigms. Lanham, MD: University Press of America.

\section{About the Authors}

Joseph G. Bock

Joseph G. Bock is an adjunct instructor of political science at William Jewell College. He also serves in the Missouri General Assembly and is

Chairman of the

House Energy and Environment Com-

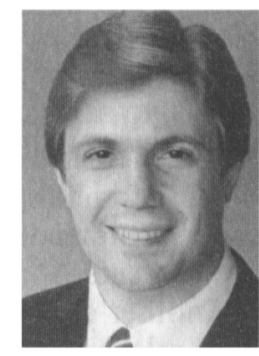
mittee. He is the author of The White House Staff and the National Security Assistant: Friendship and Friction at the Water's Edge (Westport, CT: Greenwood Press, 1987).

D. Dean Dunham, Jr.

D. Dean Dunham, Jr. is professor of English and chairman of the English Department at William Jewell College. He also serves as faculty instructional aide for the college.

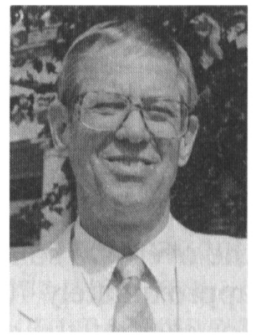

\title{
The Political Science Course Syllabi Project Selections from the Editors' Introductions to Five Introductory Course Collections
}

The APSA is conducting a project to collect and distribute exemplary syllabi for ten political science courses. The project is supported by a grant from the Fund for the Improvement of Postsecondary Education. In fall 1991, collections were prepared for introductory courses. The editors and contributors to each syllabi collection were listed in the March 1992 issue of PS: Political Science \& Politics, pp. 109-11.

Five additional syllabi collections are being completed this fall. A list of the contributors to each collection, accompanied by selections from the editors' introductions, will be featured in the March 1993 issue of $P S$. The course collections and their editors are:

Methodology, edited by John R. Freeman and W. Phillips Shively, University of Minnesota

Political Behavior, edited by Nancy Zingale, University of St. Thomas
Public Administration, edited by Naomi Lynn, Sangamon State University

Public Law, edited by Lief Carter, University of Georgia

Senior Seminar/Capstone Course, edited by Ronald Kahn, Oberlin College

To provide faculty with additional information about the introductory course syllabi collections, we are publishing selections from their editors' introductions. The editors' comments we feature reveal significant differences among the courses that reflect both the level of theoretical order in the discipline and the contribution of a course to the undergraduate curriculum. We invite faculty and graduate students to review all of the course syllabi collections in their entirety. Information about how to do so follows the editors' commentaries.

\section{General Introductory Courses in Political Science ("Introduction to Political Science," "Introduction to Politics [\&/or] Government”)}

\author{
John C. Wahlke \\ University of Arizona
}

Almost every liberal arts student's first collegiate view of the discipline of political science and its subject matter is the course syllabus handed to him the first day of class in his first political science course. We who teach students in those first encounters ought to pay attention to what, if anything, students can or should learn from reading that syllabus.

Political science differs markedly from other social and behavioral science disciplines in the way students are introduced to their subject. To begin with, a general Introduction to Political Science (or Government 
and/or Politics) is offered in only about $60 \%$ of the departments in four-year colleges and universitiesas a prerequisite to more advanced work for majors in $48 \%$, and recommended in $13 \%$-compared to Introductory American Government, which is similarly required by $80 \%$ and recommended by $11 \%$ of the departments. ... .

Another characteristic of the discipline relevant to teaching the general introduction to it is revealed by some striking but puzzling patterns in the responses to requests for information from both the Syllabus Collection Project and the Association's Departmental Service Committee for information about departmental courses. First, although the project's sample was essentially the same for all the fields included in this project survey, the over $\mathbf{4 0 0}$ solicitations yielded approximately 70 to 90 submissions for each of the other four introductory course collections, but only 20 submissions for general introductory courses, even counting several syllabi that were obviously standard American Government introductory courses required of all majors for entry to higher-level courses.

A similar pattern is found in the response and nonresponse patterns to Departmental Service Committee questions about introductory and other courses in eight sub-fields of the discipline named in the Committee's annual request for information about courses offered in 1988-89. Whereas $90 \%$ returned information about the introductory American Government and Politics course, only $74 \%$ answered about the general Introduction to Political Science. For questions about all courses in the sub-fields for which information was requested, the response rate ran from 90-87\% for Political Theory, International Relations, and Comparative Government and Politics down to 73-71\% for Public Law, Public Policy, and Public Administration (the latter figures close to the $\mathbf{7 4 \%}$ response for the general introductory course).

One can plausibly infer from the abysmally low response rate to our request for syllabi and the pattern of nonresponse to related questions in the annual Departmental Services Surveys about other courses that political scientists overwhelmingly view their discipline as a set of relatively disconnected sub-fields. . . .

Academic and intellectual curricular logic would seem to call for the general introductory course to the discipline to be where students would learn something of the general nature of the whole field and of the connection among the various sub-fields. But the course does not appear to be widely viewed in that light. It would not be surprising to find this uncertainty reflected in various ways in the syllabi used in the course.

Before considering other possible reflections of disciplinary pluralism in the general introductory course syllabi, we list here the syllabi chosen as exemplars, re-emphasizing that they are in no way a "sample" of anything. They do, however, afford as wide a view as possible, in such small numbers and space, of the conceptions of goals, approaches, content, and pedagogical techniques that are in use "out there" in the introductory-course classrooms.

\section{Introductory Courses in American Politics: Beyond Boredom and Irritation}

\section{Marjorie Random Hershey Indiana University}

Even among introductory courses, Introduction to American Politics poses unique challenges. First, it is typically a "service" course; in short, a large proportion of our students enroll because some other part of our campuses, such as the School of Business or the School of Education, has told them they must. Second, it is often an especially large course; in fact, in many universities it may be gargantuan, requiring instructors to deal with multitudes of discussion sections, teaching assistants, and the customary demands of teaching writ large.

Third, for a surprising number of students, in its current form, it may be redundant. Students entering an introductory course in international relations or political philosophy may expect to travel a road they've never traveled before. Much of the subject matter will be new, and thus potentially exciting. They can assume, with some pride, that they have now gone beyond the boundaries of their high school education. A college course in introductory American politics, on the other hand, has a familiar ring. As we will see, dealing with this familiarity requires a special effort by instructors.

We know that the great majority of college students were required to take one or more civics and/or social studies courses before graduating from high school. If their textbooks are any measure, high school social studies courses tend to be institutionoriented and fact-based. So are the early weeks of many introductory college courses. Most of our students, then, have had previous exposure to some set of presumed facts about the presidency, Congress, the courts, and other elements that they will meet again in the typical collegelevel introductory American politics course. That differentiates the introductory American course from other introductory courses in comparative politics, political theory, and international relations.

So in terms of both aims and content, a lot of introductory American politics courses lead off with material, and an approach, that will sound ominously familiar to our post-high school clientele. To be sure, the familiarity may be superficial; there is a crucial distinction to be made here between exposure and learning. But it seems likely that most of our students have been given the option to avoid learning many of these bits of information on at least one previous occasion. If a course to teach college students about American politics is designed to start from scratch, then the instructor has created a situation in which boredom and irritation are likely to be the most prominent characteristics.

Given these environmental constraints, how should we define the purpose of the introductory American course? Would it be most productive of students' learning to offer 
a more sophisticated version of high school civics, or are there alternatives?

One alternative is to begin the introductory course with topics that students don't learn in high school: behavioral research having to do with determinants of voting behavior, public opinion, ideology, intermediary groups, and so on, and then to examine the connections between these behaviors and the institutions of the national government.

Another alternative is to construct a course organized around one or more themes, so students can use their previous and current learning in a new way.....

Perhaps it is time to loosen our grip on the list of details we feel our students ought to be able to repeat before passing Introduction to American Government, and concentrate instead on conveying a few central ideas-ideas capable of provoking independent thought-about each of the major aspects of American democracy. ...

\section{Syllabi for the Introductory Course in Comparative Politics}

\section{Frank L. Wilson \\ Purdue University}

This collection is designed to present examples of creative and welldesigned course syllabi for the introductory course in comparative politics to assist instructors in designing and describing their own courses. These syllabi are among the best of some 75 syllabi submitted in response to a request from the American Political Science Association. While none may exactly match your course or interests, each has strengths that may assist you in developing your own syllabus.

In contrast to the generally fixed content for the introductory course in American politics, there is much greater diversity in the approaches to the introductory course in comparative politics. The recent changes in many parts of the world have only complicated what has always been a difficult task of explaining the varieties of foreign governmental patterns to introductory students. Indeed, these changes have introduced new flux into the teaching of comparative politics. ...

There is broad agreement among instructors teaching the introductory course on its general contents: an introduction to basic concepts and theories of comparative politics. This conceptual material is generally presented in the context of several important countries. In most cases, there is an effort to include the political experience of Western democracies, communist (and now ex-communist) countries, and Third World countries. But there are at least three different basic approaches to these broadly accepted tasks each with its advantages and disadvantages.

One approach, and the one probably most frequently used, is the country-by-country approach. After a brief introduction to the nature of comparative politics, the course sequentially treats several countries one by one, with an emphasis on the "nuts and bolts" of politics in those countries. Generally, the sample of countries includes one or more Western democracies, the Soviet Union and/or China as examples of communist polities, and one or more Third World Countries. The separate countries are usually presented in that order moving from the more familiar Western democracies to the less known Third World politics. Several of the syllabi in this collection use this approach. See, for example, the Donald Share and David Wilsford syllabi.

The advantage of the country-bycountry approach is that it provides unified views of the politics of several countries for introductory students with very little knowledge of political experience outside the United States. The teaching task is straightforward and facilitates equal treatment of several countries. At the end of the course, the student can feel some sense of familiarity with several of the most important countries in the world. The principal disadvantage is that it tends to discourage comparison and the use of the comparative method. The focus tends to be on individual countries rather than on the broader conceptual and theoretical issues of comparative politics. ...
A second approach involves emphasis on topics or concepts in comparative politics rather than on countries. While the instructor may focus on several countries as illustrative examples, the major focus is on theoretical and conceptual issues in comparative politics rather than on the "nuts and bolts" of politics in particular countries. The advantage of this topical approach is that it stresses comparative analysis. It forces students to use comparison as a method of inquiry. The topical approach facilitates the discussion of key concepts and theories that students will need as they move to more advanced courses in comparative politics. The disadvantage is that introductory students, even the bright ones, often find the topical approach too abstract. They have a difficult time putting together the information they have discussed while exploring concepts and theories into a cohesive understanding of the countries selected as examples. The beginning students who enroll in the introductory course also usually lack the informational background for them to understand brief comparative allusions to political parties or legislatures or social cleavages in foreign countries.

Some instructors seek to reconcile these first two approaches by looking at three system types with a topical focus. Instead of dealing with individual countries, this system type approach involves a comparative analysis of two or more Western democracies, communist countries, and Third World countries. The comparisons can be within or between system types. It is this regional or three-world approach to the course that will be most severely affected by the changes in the Soviet Union and Eastern Europe. It may very well be that this communist pattern may soon be little more than an historical example of a passing political order.

Another key decision involves the selection of countries if the instructor wishes to focus on specific countries. Britain is the most frequent country from the Western democratic tradition with France a close second. A growing number of instructors are 
including Japan both because of its growing international prominence and its adaptation of western democratic traditions to a non-Western setting. The Soviet Union and China are usually included of the communist and now ex-communist worlds. Even as the distinctive communist pattern disappears, it is likely that these countries will remain in introductory courses because of their prominent position in international affairs.

There is far less consistency in the selection of Third World countries. Among the most common are India, Mexico, and Nigeria. Some instructors, even while following a countryby-country approach in other parts of the world, drop that approach and shift to a more general description of politics when they move to their discussions of the Third World.

Whatever countries you choose to include, students will find an explanation for your choices useful. Are they "typical" examples of certain patterns of politics? Were they selected because of their international prominence? The Oksenberg syllabus provides a clear explanation of the selection of countries covered in his course.

\section{Teaching Introduction to International Relations: Model Syllabi}

\section{Linda P. Brady \\ Georgia Institute of Technology}

Dramatic social, political, and economic changes in the international system since the late 1980s have prompted a reassessment of how the introductory international relations course is taught. The end of the Cold War, symbolized by the fall of the Berlin Wall, the unification of Germany, and the signing of the START Treaty between the United States and the Soviet Union, has led to a flurry of activity as scholars revise their course outlines and reading lists to keep pace with daily events.

Moreover, diversification of the foreign policy agenda, to include issues such as the revolution in technology and communication, population growth, food distribution, global warming, and AIDS, has contributed to our rethinking the scope and objectives of international relations education. The introduction of new theoretical frameworks and perspectives, particularly international political economy, ecopessimism, and feminism, has broadened the traditional realist view, which formed the core of most international relations courses during the Cold War.

These trends are reflected in recent international relations textbooks, such as Barry B. Hughes's Continuity and Change in World Politics, Englewood Cliffs, NJ: Prentice-Hall, Inc., 1991, which devotes substantial attention to global economic restructuring, technological advance, and environmental constraints. These trends are evident also in the international relations syllabi submitted to the American Political Science Association's project on "Improving Teaching of the Introductory Courses: Preparation of a Good Syllabus."

More than 80 syllabi were submitted by faculty teaching introductory courses in international relations, representing diverse institutions from all regions of the country. We received syllabi from large state universities and small private colleges, from the service academies, and from church-affiliated institutions. Some syllabi focus on introducing students to major theoretical frameworks such as realism, international political economy, or feminism. Others adopt an historical perspective, focusing on balance of power models of the international system. Still others rely on contemporary issues in international affairs as jumping off points to introduce theories and concepts in international relations.

The 12 syllabi selected for inclusion in this collection share several important attributes. First, each syllabus establishes clear educational objectives and relates those objectives to specific readings, examinations, papers, and other exercises. Second, the syllabi include multiple learning tools and techniques. Some use case studies or simulations; others use films and videos, or rely heavily on the print media to illustrate significant concepts and problems in international relations. Third, each syllabus, in its own way, introduces fun- damental concepts associated with the analysis of international relations. ...

\section{Introductory Political Theory Syllabi}

\section{Peter G. Stillman \\ Vassar College}

As editor of the political theory introductory course syllabi section for the APSA syllabus project, I received about 75 syllabi. . . . In this introduction, I draw on all the syllabi I received. I also include about 15 exemplar syllabi as examples, models, and suggestions. In choosing the exemplar syllabi, I am not intending to say that they are the best or only ways to write a syllabus, nor that they are superior to other syllabi I did not choose. Rather, I aimed to represent the types of approaches to introductory political theory that surfaced in the 75 syllabi. Within each type, I chose syllabi that had interesting or uncommon readings, paper assignments, descriptions of the course contents and goal, and questions for each class or lecture, or that explained or presented the work of the course fully, explicitly, or engagingly.

What approach? The syllabi evince an extraordinary variety of modes of introducing political theory. I find seven distinct approaches. If there is a traditional approach, it would probably be a "history of political theory," and many professors do treat various major theorists in historical order over one semester or two. Two variations on the standard historical approaches exist. One concentrates on modern political thought, i.e., a selection of theorists from Machiavelli or the age of revolutions to the present. Another focuses on three to six major traditions or "regimes" in Western political history: e.g., classical (Greek) community, the modern nation state, the American experiment, the politics of republican virtue.

But not all syllabi follow a historical form. Some consider a range of contemporary issues (such as power, authority, citizenship, community, freedom, and equality); others focus on a single central issue 
(usually freedom, justice, or some directly related topic). Finally, some treat recent and contemporary ideologies, and a few emphasize how to think about politics. ${ }^{1}$

The syllabi of course do not indicate why this diversity of approaches to the introductory course. In many cases, professors may choose one approach rather than another because it fits their interests or knowledge, or because of the professor's assessment of students' interests and capabilities. Two other important factors may be at work. One is the position of the introductory course in the department's curriculum, and especially in the theory offerings. If the course is intended primarily to introduce the students to theory-i.e., if the goal is to interest students in theory by giving them some experience in thinking like a theorist on important political concerns-then a wide variety of approaches seem possible and legitimate: a course that reads Plato's Republic, Hobbes's Leviathan, Marx's 1844 Manuscripts, and Mill's On Liberty can introduce philosophical thinking about politics as well as a set of readings from contemporary books and journals (or newspapers) on issues such as equality or affirmative action. If, on the other hand, the course is intended to give some substantive background for, e.g., further specialized courses in the history of theory or in substantive issues, then specific thinkers may have to be read and certain issues covered. Or, similarly, if the course is intended to tie into other departmental courses in other fields, then the indicated approach may well be recent and contemporary ideologies.

The second factor promoting diversity among theory courses may be the condition of the canon-both conceptually and as a physical artifact. The "canon" as it exists in most theorists' minds is too big to fit into one course, even a two-semester course, ${ }^{2}$ and at present it is also unsettled or contested within the discipline. As print on the page, the canon is also unsettled and open: textbooks are used infrequently as the primary assignment (except in contemporary ideologies courses), and photocopied packets can be used easily (and, with past theorists, without legal worries about copyrights). Consequently, professors can exercise wide choice, and indeed may feel compelled to choose from the plethora of classic and contemporary texts. So no clear-cut formula exists for introductory theory, and professors have to think through how to transform and translate the canon and its questions to their students.

\section{Notes}

1. Given the self-selection, the distribution of syllabi among the seven types of approaches may indicate little. But half the syllabi fell into the one or two semester historical approach, probably about a quarter into the variations (modern political thought, political regimes) on history, and most of the remaining quarter into issues courses. I received about three contemporary ideologies syllabi (perhaps because those who teach it did not think it relevant to my charge) and about three syllabi that focused on how to think like a political theorist. (In addition, categorization was in some cases difficult or sheerly arbitrary, as with a course on "freedom in modern political thought.")

2. Though the exemplar syllabi for twosemester history courses do show how much can be included.

To order a course syllabus collection, send $\$ 5.00$ for each collection, to cover handling and postage, to:

Syllabi Collections/APSA 1527 New Hampshire Avenue, NW

Washington, DC 20036 